\title{
Влияние ориентации поверхности на характеристики высокотемпературных отжигов подложек арсенида галлия
}

\author{
Н.Л. Шварц ${ }^{1,2}$, А.А. Спирина ${ }^{1}$ \\ ${ }^{1}$ Институт физики полупроводников им. А.В. Ржанова СО РАН, Новосибирск, 630090, пр. ак. \\ Лаврентьева, 13 \\ ${ }^{2}$ Новосибирский государственный технический университет, Новосибирск, 630073, пр. К.Маркса, 20 \\ тел:+7 (383) 333-1475, факс:+7 (383) 333-2771, эл.nочта: nshwartz@isp.nsc.ru
}

DOI 10.34077/RCSP2021-71

В работе представлены результаты Монте-Карло моделирования ленгмюровского испарения подложек арсенида галлия. Анализировалось влияние ориентации поверхности подложек на характеристики неравновесных высокотемпературных отжигов. Рассматривались сингулярные и вицинальные поверхности GaAs(111)A и GaAs(111)B с разными углами разориентации. Моделирование осуществлялось в температурном диапазоне $700-1000 \mathrm{~K}$, включающем температуры конгруэнтного испарения $T_{\mathrm{c}}$ подложек с разным углом отклонения. Экспериментально показано, что при температурах отжига ниже $T_{\mathrm{c}}$ наблюдается конгруэнтное испарение, то есть галлий и мышьяк испаряются с одной скоростью, а при $T>T_{\mathrm{c}}-$ неконгруэнтное испарение, при котором мышьяк испаряется интенсивнее галлия и на поверхности формируются галлиевые капли [1]. Моделирование показало, что в процессе отжига рельеф на поверхности (111)В развивается более интенсивно, чем рельеф поверхности (111)А благодаря меньшей длине диффузии мышьяка до испарения

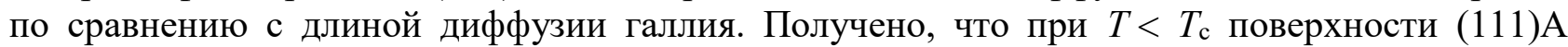
испаряются послойно, а поверхности (111)В - с образованием вакансионных островков мультислойной глубины [2]. При неконгруэнтном испарении в момент зарождения капель $\mathrm{Ga}$ скорость испарения арсенида галлия резко уменьшается вне зависимости от ориентации подложки. Показано, что температура конгруэнтного испарения, скорость испарения подложек и скорость движения капель зависят от угла разориентации поверхности. Продемонстрировано влияние капель галлия на движение ступеней вицинальных подложек в процессе отжига. Адатомы галлия, выходящие из капли встраиваются в края террас вблизи капель, замедляя испарение ступеней и меняя их рельеф. Фрагменты модельных вицинальных поверхностей (111)А и (111)В после отжига показаны на Рис.1. Обнаружено, что помимо замедления сублимационного движения капли $\mathrm{Ga}$ локально изменяют направление движение ступеней: с испарения на рост. Замедление испарения и изменение направления движения ступеней приводит к локальному эшелонированию ступеней близи капель.

Работа выполнена при поддержке программы Минобрнауки РФ (№ 0242-2021-0008).
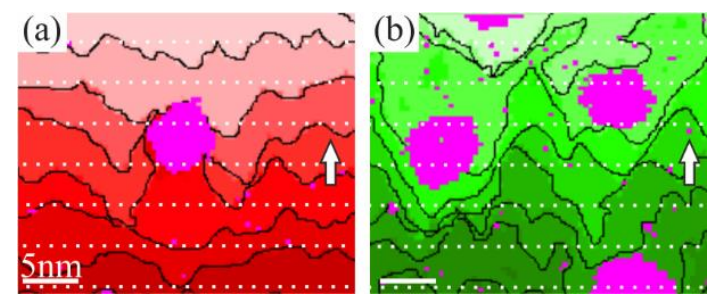

Рис.1 Модельные поверхности GaAs с углом отклонения $5^{\circ}$ (вид сверху) после отжига при $T=900 \mathrm{~K}$ : (a) - (111)A, (b) - (111)В. Розовым цветом отмечен жидкий галлий, интенсивность цвета уменьшается с увеличением высоты поверхности. Пунктиром показаны исходные вицинальные ступени, стрелки указывают направление движения капель и ступеней.

\section{Лumepamypa}

[1] S. Kanjanachuchai, C. Euaruksakul. // ACS Appl. Mater. Interfaces, 2013. V.5, P.7709- 7713.

[2] A.A. Spirina, N.L. Shwartz. // Mat Sci Semiconductor Proc. 2021. V.124, P. 106025. doi.org/10.1016/j.mssp.2021.106025). 